Muzio D, Faulconbridge J, Gabbioneta C, Greenwood R. Bad apples, bad barrels and bad cellars: a 'boundaries' perspective on professional misconduct. In: Palmer, D., Smith-Crowe, K., Greenwood, R. (eds.) Organizational Wrongdoing. Cambridge, UK: Cambridge University Press, 2016, pp.141-175.

DOI link to book

http://dx.doi.org/10.1017/CBO9781316338827.007

ePrints link

http://eprint.ncl.ac.uk/214619

Date deposited

$25 / 07 / 2015$

Copyright

This material has been published in Organizational Wrongdoing edited by Palmer, D., Smith-Crowe, K. and Greenwood, R. This version is free to view and download for personal use only. Not for re-distribution, re-sale or use in derivative works. 


\title{
6 Bad apples, bad barrels and bad cellars: a "boundaries" perspective on professional misconduct
}

\author{
DANIEL MUZIO, JAMES FAULCONBRIDGE, \\ CLAUDIA GABBIONETA, AND ROYSTON \\ GREENWOOD
}

Parmalat - formerly one of the largest dairy companies in the world went bankrupt on December 24, 2003, leaving behind a "hole" of 14 billion euros, a sum almost twice the company's 2002 sales turnover. Subsequent investigations revealed that the company's financial accounts had consistently and deliberately been falsified for each of the thirteen years that Parmalat was listed on the Milan Stock Exchange. During those years, professionals - who are supposed to act as gatekeepers (Coffee 2005, 2006) - did not (or, in some cases, decided not to) see what was going on. Deloitte - which was auditing the company's group accounts - did not raise any concerns until October 2003 when they issued a disclaimer on the company's accounts, as they could not determine the amount of a fund held by a subsidiary. Standard and Poor's constantly rated the company at the investment grade and even improved its outlook only a few months before the company defaulted. Securities analysts, similarly, remained positive on Parmalat's shares until the company was already on the verge of bankruptcy; only a few days before the fraud was detected, fifty-seven of sixty-six of their equity research reports recommended buying or holding the company's shares.

Enron's story, one of the biggest scandals in American history, is not much different, although it took place in the supposedly more developed US stock market. As in the Parmalat story, professionals did not effectively perform their ascribed roles. Arthur Andersen, the company's auditors, consistently approved Enron's accounts without raising any concerns and failed to inform "the company's audit committee 
about both the accounting policies in use at Enron and the unusual transactions the company had conducted" (Batson Report 2003: 40-41). Management consultancies such as McKinsey, which advised Enron, endorsed its strategic repositioning and praised its "asset light" strategy (Kipping, Kirkpatrick, and Muzio 2006). Not until four days before bankruptcy was declared on December 2, 2001, did rating agencies lower their ratings of the company to below the mark of a safe investment. As late as October in the same year, fifteen securities analysts rated Enron a "buy" and twelve of them recommended it as a "strong buy." Even as late as November 8, when Enron disclosed that nearly five years of earnings would have to be recalculated, eleven of fifteen analysts continued to recommend buying the stock. Only three analysts issued "holds" and one a "strong sell" - even though (admittedly in retrospect) Howard Schilit, an independent analyst, dismissively concluded that "for any analyst to say there were no warning signs in the public filings, they could not have been reading the same public filings as I did" (Forbes Report 2003).

The above stories reveal how elite professions and professional service firms are implicated in some of the world's most prominent examples of corporate corruption. Moreover, there is no apparent slackening of the trend: "If accounting scandals no longer dominate headlines as they did when Enron and WorldCom imploded in 2001-02, that is not because they have vanished but because they have become routine" (The Economist 2014: 24). Yet the professions have historically justified their influence and privileges with reference to their "gate-keeping" responsibilities (Coffee 2005, 2006), their commitment to social trusteeship (Brint 1994) and the importance of their fiduciary role (Thornton, Jones, and Kury 2005). There is, in other words, a "regulative bargain" (Cooper et al. 1988: 8; Freidson 2001) whereby the state grants the professions a monopoly and selfregulation in exchange for the commitment to maintain ethical standards and use their expertise to serve the public interest (MacDonald 1995).

Instances of wrongdoing by any occupation or organization are cause for concern, but those practised by professions such as law and accountancy are especially worrisome, for two reasons. First, the organizational form of the professional service firm is designed to ensure professional competence and integrity - so its apparent failure requires understanding. Second, and more profoundly, the professions are 
integral parts of the institutional system of checks and balances which should prevent corporate corruption of the sort practised by Parmalat and Enron. As such, the professions play a critical role in the financial markets because "capitalism cannot function without trust" (The New York Times 2012). However, as the episodes of corporate corruption reported above unequivocally indicate, they are, at best, failing in this gate-keeping role or, at worst, they are actively involved in the very forms of misconduct that they are responsible for overseeing. Instead of being lauded exemplars of ethically driven professional conduct, "major accountancy firms have become the unacceptable face of capitalism ... Scratch the surface of any financial scandal or a tax dodge and the invisible hand of major accountancy firms is highly evident" (Mitchell and Sikka 2011: 8).

In this chapter, we analyse the institutional conditions that increase the likelihood of professional misconduct. We seek to address the following questions. To what extent are professionals involved in corporate corruption? Under what circumstances do professions tend to aid rather than police misconduct? What is the relationship between professional misconduct and the institutional context in which professions operate? We define professional misconduct broadly as any behaviours, legal or illegal, that contravene normative expectations and professional codes of conduct. Under this definition, law firms advising their clients on how to shelter their income from taxation, and accounting firms turning a blind eye to their clients' accounts, are instances of professional misconduct. In both cases, professionals violate the professional norms that supposedly regulate their behaviour.

We begin by reviewing three perspectives on professional ethics: the functionalist perspective that ties professionalism to the public interest, the conflict perspective that focuses on the self-interested practices behind professional claims and the ecological perspective that ties misconduct to the changing relationships and boundaries between multiple stakeholders. We then frame and elaborate our analysis against this latter perspective by connecting professional misconduct to the tensions, risks and conflicts generated by key institutional boundaries which are increasingly fragmenting professional practice. These shifting and complex boundaries, we propose, are generating a range of blind spots, opportunities and temptations that are contributing to the incidence - and increased risk - of 
professional misconduct. We conclude by suggesting a programme for future research.

\section{Professions and ethics}

The notion that professional occupations are distinguished from regular businesses and trades by their superior moral fibre is well established in the foundational writings in the sociology of the professions (Carr-Saunders and Wilson 1933; Durkheim 1957; Parsons 1954). For these founding fathers, professions were defined by "an admirable sense of responsibility" and "a pride in service given rather than by interest in opportunity for personal profit" (Carr-Saunders and Wilson 1933: 471). As a result, professions were seen as civilizing forces that could act as "stabilising elements in society" and "centres of resistance to crude forces which threaten steady and peaceful evolution" (CarrSaunders and Wilson 1933: 497). For Durkheim (1957), the civic sense of the professions was a part of a system of moral restraints that could address the anomie of modernity, and for Carr-Saundera and Wilson (1933), the established professions were even a bastion against the barbarities of Nazism and Stalinism.

In short, for these and other functionalist writers, the professions have a normative value that comes from the role they exercise for the benefit of society, and from the superior ethics, altruism and civic conscience of their members. Similar assumptions, albeit with less hagiographic undertones, characterize the ultimately flawed taxonomic project of trait theorists (e.g., Barber 1963; Greenwood 1957; Millerson 1964), which sought to analytically distinguish professions from other occupations based on their key empirical attributes. Professional ethics based upon a public interest orientation were one of the few traits shared by most checklists.

In these functionalist and trait-based perspectives, professional misconduct is a misnomer that runs counter to the very idea of professionalism. Accordingly, this literature does not directly deal with the issue, but if it could offer an explanation it would probably be in line with the "bad apple" hypothesis (Kisch-Gephart, Harrison, and Treviño 2010), whereby misconduct results from the behaviour of rogue individuals acting against the standards and norms of their profession.

From the 1970s, an alternative and increasingly dominant perspectiveconflict theory (Freidson 1970; Johnson 1972; Larson 1977; MacDonald 
1995) - began to offer a different take on this issue. For these writers, professionalism is a "peculiar type of occupational control rather than an expression of the inherent nature of particular occupations" (Johnson 1972: 45). Crucially, it is a form of control that empowers producers vis-à-vis consumers by entrusting professionals with "occupational dominance" (Freidson 1970) over the performance of their own work, including its means, ends and the terms and conditions under which it is performed (Freidson 1970). These outcomes are the result of a conscious and systematic political project aimed at translating "a scarce set of cultural and technical resources into a secure and institutionalised system of social and financial rewards" (Larson 1977: xvii).

Professional ethics to these writers are seen as rhetoric that legitimates the privileges of monopoly, self-regulation and higher levels of income. Not only do professions not have a special moral commitment, but they also engage in self-serving behaviours. Professional misconduct, in this sense, is consistent with a "bad barrel" hypothesis (KischGephart et al. 2010) as it reflects the way that professions are designed as social systems, that is, how they are structured to prioritize their own interests over the public good. As George Bernard Shaw put it, the professions are designed to act as conspiracies against the laity (Shaw 2004).

Both the conflict and functional perspectives view misconduct (or, in the latter case, the lack of it) as an inherent and defining feature of professionalism. As such they provide an essentially static account of misconduct and give little attention to how change within and between professional occupations may contribute to its occurrence or form. Particularly important - and so far relatively ignored - are changes to the institutions of the professions - such as training and qualification regimes (Freidson 1994, 2001), ethical codes and disciplinary mechanisms (Brint 1994; Dinovitzer, Gunz, and Gunz 2015; Greenwood 2007; Reynolds 2000), or forms of governance (Greenwood and Empson 2003; Lipartito and Miranti 1998; von Nordenflycht 2014) - which, though designed to support professional standards and constrain the possibility of misconduct, are increasingly becoming undermined. In this context, in our opinion, a more unfolding, dynamic approach to professional misconduct is needed - an ecological perspective - in which misconduct is connected to shifting political and economic contexts that are disrupting the traditional institutional arrangements of the professions 
and eroding their ability to support and regulate appropriate professional behaviour.

Theoretically, the key idea and our starting point is provided by Abbott's notion of professional "ecologies" $(1988,2005)$ which, through its emphasis on professional competition, offers a dynamic view of changing relationships within and between professional occupations. According to this perspective, professions exist as parts of an interlinked system where they compete against each other to control specific tasks (Halpern 1992). These tasks are organized as jurisdictions over which professions advance more or less exclusive claims. However, because jurisdictions confer material advantages, the claiming and retention of jurisdictional boundaries are inevitably a contested process in which professions advance competing claims in front of key audiences such as the state, the public and the employing organization (e.g., Albrecht and Levy 1982; Begun and Lippincott 1987; Goode 1960, 1969; Halpern 1992; Kronus 1976).

In later work, Abbott (2005; for a similar if less developed argument, see Burrage, Jaraush, and Siegrist 1990) portrays the systems of professions as part of a broader "linked ecology" with adjacent institutions such as the state and the universities, reflecting the fact that the professionalization projects of specific occupations are constrained, supported and generally affected by the moves of social actors adjacent to them and with whom they regularly interact (Muzio, Brock, and Suddaby 2013; Suddaby and Muzio 2015; Suddaby and Viale 2011). As Abbott (2005:247) observes, "[n]ot only does a jurisdictional tactic like licensing have to succeed in the system of professions, it also has to succeed in the ecology of the state, for quite other reasons."

Abbott's focus on professional ecologies emphasizes the particular importance of "boundaries" that delineate and regulate professional jurisdictions by separating rival interests and the claims of different stakeholders. Based on his work, we identify different types of boundaries which are typically in play within professional ecologies: "jurisdictional" (boundaries between different occupational domains), "geo-political" (between different national realms) and "ecological" (between stakeholders such as practitioners, clients and employers). Importantly, professional ecologies and their boundaries are inherently unstable because of endogenous struggles within the system of the professions itself and exogenous developments in adjacent fields. The redrawing of existing boundaries allows groups to colonize new 
jurisdictions, exploit new opportunities, avoid regulatory constraints and diminish existing obligations. Professional ecologies, in this sense, are in constant evolution, especially "on the fringes" where different sectional claims and interests are more likely to come into conflict. Indeed, Abbott contrasts relatively stable professional heartlands with the chaotic and disrupted lives along the frontiers. In his words, "boundaries are zones of action because they are zones of conflict" (Abbott 1995: 857).

In this context, professional misconduct arises from the re-drawing of jurisdictional, geo-political and ecological boundaries within and between professional ecologies. In particular, changing boundaries may undermine existing oversight regimes, fuel conflicts of interest, create regulatory blind-spots and generate opportunities for unorthodox, illegitimate and even illegal forms of behaviour. Regulatory, demographic and technological change, in other words, can undermine existing professional and regulatory institutions and disrupt established jurisdictions and their associated organizational forms and work practices (Brock, Powell, and Hinings 1999; Leicht and Fennell 1997). In this context, professional misconduct is consistent with a new "bad cellar" hypothesis, as it arises from the relationships and boundaries between different stakeholders (barrels) in a broader ecological system (cellar). In the rest of this chapter we elaborate how the three sets of boundaries here identified can contribute to professional misconduct.

\section{Changing professional boundaries and misconduct}

\section{Jurisdictional boundaries}

Jurisdictional boundaries are one of the key elements of the "system of the professions" (Abbott 1988). They identify different professional domains and assign them specific tasks, competences and obligations (Abbott 1988; Freidson 1984, 1994). By doing so, they create an order within the system of professions that, although dynamic and constantly changing, allows it to function in a rather effective way and to survive over time (Albrecht and Levy 1982; Begun and Lippincott 1987; Goode 1960, 1969; Halpern 1992; Kronus 1976). Jurisdictional boundaries, however, may also create opportunities for professional misconduct. We see two main ways by which this can happen. 
First, professional misconduct can be the consequence of professionals and professional service firms crossing over different professional jurisdictions. For example, conflicts of interest may arise when audit firms offer their clients non-audit services. When this happens, as highlighted by Levitt (2000), firms may use the audit "as a springboard to more lucrative consulting services" by providing only a cursory audit in the hope that doing so will enhance their relationships with a client. Or, firms may compromise the exercise of professional scepticism when evaluating financial statements in favour of primarily commercial interests. According to the US Securities and Exchange Commission, audit firms that offer both audit and consultancy services may eventually "impair investor confidence in auditor independence and lead to declining confidence in public capital markets" (SEC 2000). Similarly, a conflict of interest may arise when law firms provide consulting in addition to legal services (Rosen 2002), or when securities analysts, who are supposed to produce independent assessments of a company's stock, succumb to the pressures exerted by their employer to issue "more favourable" recommendations (Barber, Lehavy, and Trueman 2007; Dugar and Nathan 1995; Hayward and Boeker 1998; Lin and McNichols 1998; Michaely and Womack 1999; O’Brien, McNichols, and Hsiou-Wei 2005).

The idea that professional misconduct can be the consequence of crossing jurisdictional boundaries is well established (Sikka and Willmott 1995). Much less attention, however, has been paid to a second way by which jurisdictional boundaries may lead to professional misconduct. Reliance upon (rather than the crossing of) jurisdictional boundaries creates the risk of misconduct arising from "institutional ascription" (Gabbioneta et al. 2013; Gabbioneta, Prakash, and Greenwood 2014).

Gabbioneta et al. (2013) emphasize that most instances of corporate corruption involve several professional firms. Accounting, law, consultancy, investment firms and rating agencies are often implicated at the same time, confirming Palmer's (2012: 36) suggestion that "most wrongful courses of action require at least the tacit cooperation of others and thus are at least nominally collective". For this reason, attention should be given to the network of gatekeepers rather than to dyadic relationships such as those between auditors and clients. It is in this context that Gabbioneta et al. (2013) introduce the idea of institutional ascription. They propose that several conditions - the 
jurisdictional division of labour among professionals, the overspecialization of professional work (Leicht and Fennel 1997) and the increasing volumes of activity with which professionals and professional service firms have to cope (Braun 2000) - may push professionals to uncritically and unduly rely on the work performed by other professionals and/or professional service firms. It is this passive acceptance of the work of others that opens up the way for misconduct.

The most obvious example of this pattern of behaviour is the heavy reliance upon the reports of auditors. In the Parmalat case, professional reliance was clearly evident, first in the relationships between two accounting firms and later in the relationships between accounting firms, analysts and rating agencies. Gabbioneta et al. (2014) show how Deloitte's "unconditional opinion" on the company's group accounts relied on Grant Thornton's audit of several of Parmalat's subsidiaries, including Bonlat, the group's "garbage can." Similarly, Arnold and Sikka (2001: 483) point out how, in the case of the Bank of Credit and Commerce International (BCCI), the "appointment of two auditors limited the scope of each auditor authority and facilitated BCCI's financial manipulation."

Once audit reports are available they are often uncritically accepted by other professions - even those that are supposed and claim to exercise independent scrutiny and judgement - because "a green light from an auditor means that a company's accounting practices have passed muster" (New York Times April 13, 2008; in Sikka 2009). Credit rating agencies, for example, often base their ratings on financial statements that they assume have been appropriately checked. The Public Prosecutor in the Parmalat case was especially critical of rating agencies because they "did not develop a true analysis of the company's financial statements," even though doing so would have shown that these statements "were abundantly false" (Public Prosecutor, Parma). Similarly, the US Senate Committee investigating the role of rating agencies in the Enron case decried their behaviour because they "did not perform a thorough analysis of Enron's public filings; did not pay appropriate attention to allegations of financial fraud; and repeatedly took company officials at their word, without asking probing, specific questions despite indications that the company had misled the rating agencies in the past" (Senate Governmental Affairs Committee 2002: 108).

The chain of reliance on other professionals in the above stories also implicates securities analysts, who formulated their investment 
recommendations using financial data that they presumed had been diligently audited and had been appropriately examined by the credit rating agencies. This reliance occurred despite the proclamation of analysts that they "exercise independent professional judgment when conducting investment analysis, making investment recommendations, taking investment actions, and engaging in other professional activities" (CFA 2013). As reported in the New York Times (2001), one analyst "persisted in recommending the (Enron) stock" because he did not "think accountants and auditors would have allowed total shenanigans." Or, as another securities analyst candidly admitted, "we actually do something similar to an act of faith ... if we know that those who have more information than we do have already expressed a positive opinion, to some extent we raise our hands ... and consider the financial situation as given ... we do not question ... [issues] on which rating agencies have already given their opinion" (Gabbioneta et al. 2014).

Coming full circle, audit firms frequently rely on the work of law firms. When asked why Arthur Andersen did not report on Enron's suspicious accounting practices, Nancy Temple - in-house attorney for Arthur Andersen - answered that it was "because Vincent \& Elkins had said there was no problem and that no further action would be necessary." Marco Verde - one of the auditors working for Parmalat testified that he had agreed with the company on the value of a certain transaction because the law firm assisting the company had not raised any concerns about it (Court of Milan 2008).

Institutional ascription can arise from several motivations and perceptions. Observers may misunderstand the basis of others' jurisdictions and attribute a process of diligence and detailed scrutiny that those professions would not claim. Or, it could arise from professional failure - as when an auditor fails to detect a wrongdoing within a client's organization. Or, it could stem from the inappropriate actions of a professional (as in the Parmalat case). Whatever the initial cause, however, the central thrust of the institutional ascription thesis is that any weakness diffuses and infects a professional network and has an amplifying effect - as more and more professions sign off, the less likely that wrongdoing will be inspected and exposed.

Paradoxically, therefore, the existence of jurisdictional boundaries may either decrease or increase the possibility of professional misconduct. It may decrease it by preventing the emergence of conflicts of 
interests that would arise from professional service firms crossing jurisdictional boundaries. Yet, boundaries may increase the risk of professional misconduct, because of the processes of mutual ascriptions of professional diligence that take place among professionals. Both possibilities - boundary crossing and boundary respect - it is worth noting, increase not only the risk of professional misconduct but also the chances that corruption by clients will occur and remain undetected.

\section{Geo-political boundaries}

While not at the centre of Abbott's analysis (but see Krause 1996; MacDonald 1995; Burrage and Torstendahl 1990), professional ecologies and their regulatory regimes have historically existed within national (or in some cases regional) contexts. Differences in qualification frameworks and codes of practice mean that expectation and definitions of professional conduct vary across geo-political boundaries. In a globalizing world, however, professional work is increasingly conducted across these boundaries, and as such geo-political boundaries are an increasingly significant risk factor in professional misconduct (see Faulconbridge and Muzio 2012).

The crossing of geo-political boundaries is reflected in the rise of the large multinational professional service firm which is increasingly replacing the national partnership as the key organizational arrangement for elite professional activity (see Cooper et al. 1996; Faulconbridge and Muzio 2008). The largest multinational law firm Baker and McKenzie has offices in excess of 40 countries and employs over 10,000 lawyers. The "Big Four" accountancy firms are some of the most globalized organizations in the world. PricewaterhouseCoopers, the largest, has offices in over 150 countries and almost 200,000 employees (Empson et al. 2015). The transnational scope of these organizations creates three new risks and opportunities for professional misconduct.

First, as they cross geo-political boundaries, professionals may face uncertainty over the nature and source of their obligations - Nagel's (2007) dilemma of double deontology. Historically, professionals derived their normative obligations from the specific geo-political jurisdictions in which they were based (Krause 1996). However, as Etherington and Lee (2007: 96-97) sharply illustrate, in an era of frequent boundary crossing, "we might not be too surprised to find 
an Australian lawyer working in the Brussels office of a New York law firm on a contract for a Japanese client with a German counterpart, which is governed by English common law, but in which disputes are to be referred to the International Chamber of Commerce's International Court of Arbitration in Paris." The result is an ethical conundrum for professionals and clients caught between national jurisdictions and their respective deontological rules. Nicolson and Webb (1999) suggest that such situations of double (or perhaps multiple) deontology lead to systematic uncertainties and unintentional misconduct as professionals struggle to understand and reconcile the demands of competing jurisdictions.

A good example of double deontology relates to Swiss banks and their US clients (see Broom and Bandel 2014). To prevent money laundering and tax evasion, in 2010 US authorities demanded that Swiss banks with branches in the US reveal details of accounts held in Switzerland by US nationals. This immediately left Swiss professionals in a situation of double deontology. Complying with the disclosure request would violate Swiss privacy laws, but not doing so would violate US laws. The Swiss Secretariat released a statement in 2012 noting that "the implementation of these provisions is generating high costs and legal uncertainty worldwide" (quoted in Novack 2012). Ultimately, a special agreement had to be reached that allowed Swiss privacy laws to be broken. This involved Swiss professionals gaining consent from clients to break Swiss laws. A related but slightly different example is provided by Smets, Morris and Greenwood (2012) who found that German and UK lawyers working in the same firm initially found it difficult to collaborate on cross-border transactions because differences in their respective deontological codes made certain actions illegal in one jurisdiction while legal in the other. Again workarounds were needed, or what Smets et al. (2012) refer to as "situated improvising." Both examples raise questions about the malleability of rules and standards and, as we demonstrate below, the potential to enable wrongdoing through forms of arbitrage.

A similar form of risk relates to the trend towards off-shoring (see Daly and Silver 2006; Sako 2015). In such scenarios, double deontology is again a problem because it is not typically evident which set of ethical standards should apply. Should it be those of the offshore jurisdiction in which the work is completed, or those of the jurisdiction of the professional service firm off-shoring the work? Or should it be 
those of the jurisdiction where the client is located? Such uncertainty led the UK Financial Reporting Council to question whether the offshore activities of accountancy firms are sufficiently managed to ensure adherence to ethical standards (Crump 2013).

A second risk concerns more intentional misconduct. Off-shoring provides corporations with opportunities to escape the reach of national regulations and regulators - as illustrated by the case of off-shore financial centres. These are not a new phenomenon (see, for example, Roberts 1994) and have significant financial implications - Sikka and Hampton (2005: 327) estimate that in 2001 they cost the US government $\$ 311$ billion in tax revenues. Importantly for our purpose, off-shore centres could not operate without the support of professionals, especially accountants and lawyers and those holding new forms of expertise, such as asset and wealth managers (see Harrington 2015; Wójcik 2013). As Palan, Murphy and Chavagneux (2010: 13) observe, it is no coincidence that accountants from the Big Four are found in nearly all offshore financial centres and that their client base in these jurisdictions is almost exclusively comprised of corporations seeking to minimize their tax liabilities. Indeed, following the collapse of WorldCom, a US Senate Permanent Subcommittee on Investigations revealed that the Big Four accountancy firms had developed multiple tax "products" designed to exploit differences across national jurisdictions and had done so without apparent regard for their broader professional and fiduciary obligations (Sikka and Hampton 2005: 333). Similarly, in the UK, KPMG developed a tax-avoidance scheme which used Jersey as an offshore centre in order to reduce sales tax liability, a practice since deemed illegal throughout the EU (Sikka and Hampton 2005: 337). In Australia, lawyers enabled the movement of the entire James Hardie company off-shore to the Netherlands in order to minimize potential liabilities arising from the company's asbestos-based products (Le Mire 2007). A national outcry forced the Australian Federal government to step in to top-up the compensation fund available to plaintiffs. In these situations the behaviour of professionals may not necessarily involve illegal actions, but their advice can be construed as a form of normative misconduct. As Urry (2014:44) notes, "even George Osborne, the Conservative Chancellor of the Exchequer in the UK, describes 'aggressive tax avoidance' as 'morally repugnant'."

The wider issue relates to the responsibility that professionals hold in the use and impact of their advice. In many instances, professional 
advice which is legally sound enables and supports wrongdoing by their clients, implicating professionals in the transgression of normative standards. After the demise of Lehman Brothers it became clear that the Repo 105 instrument used to remove liabilities from its balance sheet and the ultimate cause of the firm's collapse was adopted as a result of a legal opinion provided by the London office of Linklaters. This opinion stated that under English law Lehman's treatment of Repo 105's instrument was legal. However, Lehman had previously been advised that under US law such a use of a Repo 105 instrument would not be permitted. Professionals at Lehman's had exploited their firm's ability to cross geo-political boundaries to seek a favourable professional opinion elsewhere, in order to circumvent its own national regulations. Moreover, lawyers at Linklaters failed to consider how technically sound legal advice might be exploited and have unintended implications - something perfectly feasible given Linklaters' activities as a global law firm in New York City. As Kershaw and Moorhead (2013: 51) note, the question arises: "Whether the lawyer giving the true sale opinion perceived, or ought to have perceived, that providing the opinion was likely to give rise to a real risk of accounting or securities breaches. Or, to echo Lord Nicholl's words set forth above in relation to dishonest assistance, if they were not so aware, had they deliberately closed their eyes and ears to this risk?"

Similar questions exist with regard to the role of professional services firms in facilitating tax avoidance. Burger, Mayer and Bowal (2007: $49)$ note that clients are often "advised in 'comfort or opinion letters' issued by law firms to the effect that the tax shelters are 'perfectly legal'," despite the fact that by exploiting an off-shore jurisdiction the client is breaking laws in another country in which they operate. Geopolitical boundary crossing, then, raises not only new deontological uncertainties but generates situations in which professionals can become implicated in corporate wrongdoing.

The third risk associated with the crossing of geo-political boundaries is the lobbying of national governments for regulatory changes that increase the possibility of misconduct. As Flood (2011: 510) emphasizes: "the size and scope of global law firms has made them difficult to encompass within a single regulatory jurisdiction" and "put them beyond the reach of effective national regulation" (for an accounting example, see Greenwood and Suddaby 2006). Moreover, 
their scale gives them the ability to pressure national governments for favourable regulatory treatment.

A clear example was the threat by the Big Four accountancy firms to relocate to Jersey if the British government failed to introduce "limited liability partnerships" (Mitchell et al. 2002). The Big Four engaged two law firms in London (Slaughter \& May and Simmons \& Simmons) and one in Jersey (Mourant du Feu \& Jeune) to introduce limited liability partnerships in Jersey. They then used the threat of relocation to successfully lobby for similar legal arrangements to be introduced in the UK. The motivation for introducing this new organizational form was to limit liability in cases involving professional negligence. In effect, the ability to move across national boundaries was used to undermine the concept of joint and several liability that has traditionally been portrayed as a fundamental mechanism for reducing the risk of professional misconduct (Greenwood and Empson 2003; Briscoe and Von Nordenflycht 2014).

The size and significance of global professional services firms gives them not only leverage over national regulators but also influence over the design of international regulatory arrangements. As Flood points out, "global capitalism has been predicated on the rule of law ... and among its chief architects are the large international law firms" (2011: 511, emphasis added). In performing this role, firms accomplish two things. First, as Suddaby, Cooper and Greenwood (2007: 334 - see also, Arnold 2005; Faulconbridge and Muzio 2012) note, "the historical regulatory bargain between professional associations and nation states is being superseded by a new compact between conglomerate professional firms and transnational trade organizations." This new compact uses the growing size and the power of global professional service firms, in alliance with international organizations such as the WTO, to support deregulatory agendas and develop globally integrated markets for professional expertise. Five US law firms, for example, formed the backbone of the legal division of the Council of Service Industries which lobbied hard for the de-regulation of professional services markets as part of the WTO's GATS agreement (Terry 2001).

Second, the legitimacy and effectiveness of national regulatory frameworks are being constantly undermined. The global law firm, for example, has managed "to sideline the inconvenience of conflict of interest rules while continuing to pay lip service to them" (Flood 2011: 508-509). Caramanis (2002: 400) describes how in the 1990s the then 
"Big Five" accounting firms "co-ordinated or at least initiated" a series of reforms to the Greek audit profession, which made it easier for them to employ foreign accountants in Greece. This made the Greek accountancy profession "gravely concerned as these measures (the new qualification exams [especially]) could call into question its [the Greek profession's] standing and reputation" (quoted in Caramanis 2002: 400). Similarly, residency requirements in Canada that "protect(ed) consumers from malpractice by making disciplinary control more practicable and by facilitating the ability of injured parties to sue for negligence" were undermined by WTO free trade regimes (Arnold 2005: 313).

\section{Ecological boundaries: clients, investors and employers}

A series of "ecological" boundaries separate and regulate professional relationships with clients, employers and, increasingly, financial investors (Abbott 1988, 2005; Burrage et al. 1990). These boundaries establish professional duties by specifying the rights and obligations of different parties - such as the duty to avoid conflicts of interest or to ensure client confidentiality (Dinovitzer et al. 2015). They are also designed to limit the possibility that professionals may be unduly influenced such that they fail to observe their own deontological obligations. Three boundaries are especially noteworthy: between professionals and their clients; between professionals and the organizations in which they work; and, third, those between professional firms and investors.

\section{Boundaries between professionals and clients}

It used to be thought that clients are less knowledgeable and organized than their professional advisors and therefore less able to define and ensure that their interests are appropriately addressed (Johnson 1972). Yet, in the corporate world at least, clients are becoming increasingly sophisticated (Sturdy 1997). Furthermore, they are increasingly taking a more short-term and transactional approach to professional relationships, constantly reviewing their suppliers (Broschak 2015). The outcome is client capture: "companies tend to select auditors who will provide a clean opinion as cheaply and quickly as possible. Similarly, accountants who discover irregularities may be better off asking management to make minor adjustments, rather than blowing 
the whistle on a mis-statement that could embroil their firm in costly litigation" (The Economist, December 13, 2014). In this context, auditors have become "dozy watchdogs" (The Economist 2014: 25). As a result, boundaries originally designed to protect clients acquire a new significance in protecting professionals themselves (Heinz 1982).

"Client capture" (Dinovitzer, Gunz, and Gunz 2014; Gabbioneta et al. 2014; Gunz and Gunz 2008; Leicht and Fennel 2001) refers to situations where advice is tailored to the commercial interests of clients and weakens the professional's fiduciary obligations to the broader public. In other words, the interests of clients are prioritized to the point where the "social trusteeship" (Brint 1994) responsibilities of professionals are compromised. Although capture may occur over relatively mundane issues (Dinovitzer et al. 2014), it particularly matters where it affects the "gatekeeping" role of the professions - such as their commitment to the administration of justice or to the accuracy of financial statements.

The implications of client capture are starkly illustrated by the involvement of the professions in corporate wrongdoings such as those committed by Enron, WorldCom, Tyco and Parmalat. In each case, a professional firm was deflected from behaving "professionally" either by explicit pressure from the client or by the implicit fear of losing the client. In the case of Enron, "[Arthur] Andersen team members routinely succumbed to demands for certification from Enron management," spectacularly failing in their obligations towards third parties, especially investors (Macey and Sale 2003: 1179). In the legal profession, to give one example, Australian large law firm Clayton Utz was complicit in the strategy of its client British American Tobacco to destroy documentation so as to minimize litigation risks (Cameron 2002; Parker 2004).

Rating agencies have been similarly criticized for their lack of independence. As Crotty (2009: 566) observes, "ratings agencies are paid by the investment banks whose products they rate. Their profits therefore depend on whether they keep these banks happy ... If one agency gave realistic assessments of the high risk associated with these securities while others did not, that firm would see its profit plummet. Thus, it made sense for investment banks to shop their securities around, looking for the agency that would give them the highest ratings and it made sense for agencies to provide excessively optimistic ratings." Such a view is echoed by Partnoy (2009: 432), who argues that "credit-rating 
agencies ... sell not information, but keys that unlock the financial markets" and that, as a consequence, issuers have strong incentives to look for the agency that would give them the highest possible rating.

A growing literature seeks to identify the circumstances that increase the likelihood of client capture - or at least the risk of its occurrence. For Sharma (1997), who uses the term client control, it is most likely to occur in situations where clients have alternative providers, where professionals make significant investments in a particular client relationship and where there is a high degree of dependency upon a particular client. Macey and Sale (2003) refer to the size of the client, the dependency of the firm upon revenues from a particular client and the weakening of collective accountability implied by the limited liability partnership format. Klimentchenko (2009) and Sikka (2009), referring to the relationship between auditing and consulting, stress the impact of "cross selling" and how this can compromise fiduciary services.

Several factors are supposed to reduce the risk of client capture. Since the Sarbanes-Oxley reforms of 2002, the extent of consulting that can be provided to an audit client has been constrained. Similarly, many countries worldwide have introduced mandatory audit rotation every three to five years. But the evidence to date is that these factors are, at best, only partially effective in reducing the risk of client capture (e.g., Abbott, Parker, and Peters 2004; Blouin, Grein, and Roundtree 2007; Cullinan 2004; DeFond and Francis 2005; Myers, Myers, and Omer 2003; Ribstein 2003).

Boundaries between professionals and employers. A particularly important ecological boundary, and, again, one that is changing and that has potential significance for the possibility of misconduct, is that between the individual and the employing organization. The relationship between professionals and bureaucratic organizations has long been a concern in the literature and was, initially, considered to be an area of tension because of the (assumed) inherent conflict between professional and bureaucratic contexts. It was supposed that professionals would find it difficult to sustain their professional commitment (e.g., Goode 1957). However, "this line of reasoning has not been supported by empirical research. Professionals have actually adapted well to work in large organizations" (Suddaby and Viale 2011: 423). Moreover, as noted above, professionals have developed a particular governance form - the "professional partnership" - which is intended to underpin and reinforce professional values. 
However, as members of professions have moved from being primarily self-employed or employed in modest-sized firms to become employees of increasingly large firms, the boundary between the professional as a member of a profession and as an organizational employee has assumed high significance (Ackroyd and Muzio 2007; Larson 1977; MacDonald 1995). It has long been recognized that organizational size can undermine - at least to some extent - the traditional autonomy and discretion provided by collegial professionalism and can raise the risk of ethical challenges (Brock et al. 1999; Cooper et al. 1996; Greenwood and Hinings 1993).

The reason why this particular boundary has worrying consequences is twofold. Larger firms can unwittingly distance their professionals from the cultural and normative influence of the broader professional community. Thus, for example, large English law firms have largely opted out from national vocational training processes and in conjunction with commercial providers like BPP University developed their own in-house training programmes (Faulconbridge and Muzio 2012; Malhotra, Morris, and Hinings 2006). Through these programmes, trainees are socialized into the organization's systems, practices and values. This distancing process is further facilitated by the development of increasingly sophisticated identity management techniques designed to control and align individual subjectivities with organizational priorities (Anderson-Gough, Grey, and Robson 1999, 2000; Cooper and Robson 2006; Covaleski et al. 1998; Grey 1998). Thus, through "the use of a bundle of increasingly sophisticated HR practices such as selective recruitment, in-house training, performance appraisal and mentoring these firms mould their recruits" to fit in with their values and priorities (Flood 2011: 510).

The second way by which size and organizational status might compromise professional norms is that professionals within a large and prestigious firm are more susceptible to the gentle and often implicit expectations to do things in a particular way. A firm's prestige provides a form of "structural assurance" that its way of doing things is appropriate (Grey 2003; Wilson et al. 2008; Smets et al. 2012). Structural assurance, in other words, "is especially apposite in professional settings because it lowers professional concerns that organizational practices and expectations are appropriate, even though they may run counter to institutionalized norms of conduct" (Smets et al. 2012: 897). Crucially, this tends to facilitate misconduct as 
professionals in prestigious firms assume that their objectives are "safe and fair" (Wilson et al. 2008: 989). Importantly, structural assurance applies not only to employees but to other stakeholders, such as other organizations in broader networks of expertise, and to regulators, who are likely to exercise less scrutiny to large firms (Grey 2003; Smets et al. 2012).

Boundaries with investors. Finally, a recent and still developing boundary that may represent an increasingly important source of ethical tensions and dilemmas resides between professionals and outside investors. Traditionally, professionals have been organized as sole practitioners or as part of "partnerships," which merge ownership with managerial control (Empson and Chapman 2006; Greenwood, Hinings, and Brown 1990; Greenwood and Empson 2003; Maister 1993; Briscoe and Von Nordenflycht 2014). As such, partners are jointly and severally liable for each other's liabilities, a pattern of responsibility intended to ensure the quality and integrity of professional work. Joint liability, in other words, at least in theory, should motivate professionals to monitor each other and therefore safeguard the interests of clients and the broader public.

A distinctive feature of the partnership format - at least until recently - has been the prohibition of external investors. There was to be no internal "representatives" (i.e., proponents) of the commercial "logic" (Pache and Santos 2010). Instead, the professional logic was to be ubiquitous and thus nurtured and protected. Yet over the last few decades (Faulconbridge and Muzio 2009; Greenwood and Empson 2003; Briscoe and Von Nordenflycht 2014) an increasing number of professional service firms, especially management consultants and investment banks (Briscoe and Von Nordenflycht 2014), have restructured themselves as publicly listed corporations - moving away from and potentially undermining the motivation and value of peer control. This shift has been proposed as a major reason why, for example, investment banks became more commercially oriented (Santoro and Strauss 2013).

Some occupations, notably management consulting, adopted the professional partnership form because it gave them symbolic legitimacy. It made them appear professional because that was the format associated with the established professions - especially law and accounting for whom the partnership format was mandatory (McKenna 2006). Recently, however, some jurisdictions - such as 
New South Wales in Australia, and England and Wales - have allowed external investment in and ownership of law firms. Two Australian law firms have listed on the stock exchange and expanded through highprofile acquisitions in the UK (Dowell 2012; Gannage-Stewart 2014; Briscoe and Von Nordenflycht 2014). The UK law firm Gateley was floated on the London Stock Exchange on June 8, 2015 (Manning 2015), soon to be followed by the larger firm Irwin Mitchell (The Lawyer 2015).

The move to allow external shareholders is significant because they represent another key stakeholder within professional ecologies and, as such, provide another set of relationships and tensions that have to be managed by professional firms and their professional associations. As indicated by the quote below, which is taken from the prospectus of Slater \& Gordon, for a publicly listed law firm securing a return on investments potentially clashes with fiduciary obligations towards other stakeholders:

Lawyers have a primary duty to the courts and a secondary duty to their clients. These duties - including the attendant responsibilities such as client confidentiality and the rules relating to legal professional privilege - are paramount given the nature of the company's business as an incorporated legal practice. There could be circumstances in which the lawyers of Slater \& Gordon are required to act in accordance with these duties and contrary to other corporate responsibilities and against the interests of Shareholders and the short-term profitability of the company (Slater and Gordon 2007).

The fear, hinted in the quote and articulated elsewhere is that the duty to investors to maximize returns on their investment may compromise standards (Markle 2014; Parker 2004; Rayne 2014). Firms may come under pressure to maximize billing from existing clients through aggressive cross-selling, or to compromise quality in order to boost their profitability. In effect, the breaching of this boundary may reinforce the client capture dynamics described above. It is, however, too early to know how these changes in the ownership boundaries will play out, but not all observers are pessimistic. Some have argued that outside investors could reduce the incidence of misconduct by imposing higher regulatory standards and tightening internal controls (Fortney and Gordon 2013; Parker 2004; Parker et al. 2008; Parker, Gordon, and Mark 2010). Nevertheless, the growing role of investors as an important stakeholder in professional ecologies and the conflicts of 
interest that this additional complexity may generate represent an important new source of tensions and, potentially, of misconduct.

\section{Conclusions and future research agenda}

Our chapter supports the view that professional misconduct arises from the transformation of professional institutions rather than being inherent in the nature of the professions themselves. Our analysis places particular emphasis on changing relational patterns within broader professional ecologies. At the heart of our argument is the importance of boundaries with professional ecologies, as these demark distinct remits, roles and responsibilities and regulate the competing claims of different stakeholders. We have identified jurisdictional, geopolitical and ecological boundaries, reviewed changes to them that are destabilizing professional ecologies, and linked these shifts in, and pressures upon, boundaries to professional misconduct.

We have proposed that, in some cases, boundaries may simply be too weak. Clients and employers may too easily override the deontological obligations and fiduciary duties of individual professionals. Similarly, within multi-disciplinary firms, boundaries between different professional groups may be too thin and porous to provide an effective barrier against conflicts of interest and opportunistic behaviour. In this most obvious of scenarios, boundaries simply fail in their objective to separate distinct remits, interests and stakeholders. However, in some situations the opposite problem arises: boundaries may be too strong. Boundaries can provide barriers that deprive professionals of the full picture and cloud their professional judgment. They can create blind spots and lead to processes of collective myopia. In other situations, boundaries create uncertainties or dilemmas where existing regulatory and normative orders are weakened if not suspended. In a globalized professional services market, the gaze and reach of national regulators are increasingly compromised. The result is a liminal place characterized by ambiguity and increased opportunities for questionable experimentation and entrepreneurial behaviours. Indeed, our analysis suggests how professional firms may actively exploit the gaps and inconsistencies between national boundaries on behalf of themselves and their clients. Thus on the basis of our conceptual framework, we suggest a "bad cellar" hypothesis that ties misconduct to the contested and shifting boundaries between different actors in broader ecological 
systems. While the "bad apple" and "bad barrel" hypotheses emphasized the role of rogue individuals and flawed organizational designs, we invite researchers to broaden their focus to consider how misconduct may arise at the next level of analysis, that is, on the boundaries between actors within linked ecologies.

\section{Future research agenda}

Our conceptual framework calls for a programme of empirical work to measure, elaborate and confirm (or modify) the arguments developed here. This is particularly true with regard to the relationship between boundaries and professional misconduct. For instance, to what extent are recent regulatory changes and developments with professional ecologies reducing the scope for professional misconduct? Obvious examples include legislation introduced in the wake of Enron and Parmalat, such as the Sarbanes-Oxley Act in the US, which sought to re-regulate the relationship between professionals and their advisors and reinforce jurisdictional boundaries by re-asserting the separation of auditing from consulting. On the other hand, legislation such as the Legal Services Act (2007) in England and Wales introduces new stakeholders (i.e., investors) within professional ecologies and potentially creates new sources of tensions that have to be managed. These may lead to increased opportunities for misconduct or help to bring in more comprehensive ethical infrastructures which help to manage such risks. In this context, it is very important to ask, how are recent regulatory reforms affecting professional ecologies? What is their impact on professional misconduct? How can new regulatory risks be appropriately managed? Related to this, there needs to be a further debate on where professional regulation is best located. Historically, professional occupations have admitted and regulated individual practitioners. However, following the rise of the large professional services firm, the emphasis has somewhat shifted towards entity regulation (Flood 2011). Perhaps, on the basis of the analysis developed here, professional regulation should also take a more ecological view and focus on the boundaries between different actors and jurisdictions

Connected to this point, we need to better understand what factors are likely to weaken and compromise existing boundaries. For instance, is capture more likely to occur within stable long-term relationships, where there may be a high degree of proximity between 
clients and their advisors, or in transactional relationships, where professionals are under pressure to retain increasingly mobile clients? Is the presence of outside investors going to exercise new pressures towards misconduct or will they bring enhanced regulatory regimes which may reduce these risks?

We also need more research on the relationship between national regulatory frameworks and the new transnational regimes which are emerging, around agreements such as GATS, the EU and NAFTA. While professional practice is increasingly global and requires a global oversight, it has historically been regulated at the national level. Although inevitable, the re-scaling of regulation from the national to the transnational level may undermine existing arrangements and leave behind a series of "black-holes" where professional practice can escape proper oversight (Faulconbridge and Muzio 2012). As such, more research needs to be focused on the relationship between established national and developing transnational regimes and its likely impact on the potential for professional misconduct. Which regulatory powers and competences are best left at the national level and which at the transnational level? What is required to ensure an adequate dialogue and coordination between different regulatory levels? What is the best way to regulate global professional services firms?

Finally, more research is required in other than Anglo-Saxon contexts. There are significant national variations not only in how professional ecologies are structured (Burrage and Torstendhal 1990; Faulconbridge and Muzio 2007) but also in corporate wrongdoing patterns. Yet these differences have not been adequately explored. We need to understand how professional ecologies in continental societies, which are more closely structured around the state and characterized by stronger jurisdictional boundaries and tighter levels of regulation (Paterson, Fink, and Ongus 2003), shape professional patterns of misconduct. Coffee (2006), for example, makes a distinction between continental models, where cases of corruption often involve strong block-holders (like Tanzi at Parmalat) transferring resources from the company to themselves, and Anglo-Saxon contexts, where fragmented shareholding is associated with wrongdoing by managers who engage in earnings manipulation in order to inflate the value of their variable remuneration. Given these differences in context and the form of wrongdoing with which they are most associated, what is their link with professional misconduct? There is much we still need to know. 


\section{References}

Abbott, A. 1988. The System of Professions: An Essay on the Division of Expert Labor. University of Chicago Press.

Abbott, A. 1995. "Boundaries of social work or social work of boundaries?" Social Service Review 69: 545-562.

Abbott, A. 2005. "Linked ecologies: States and universities as environments for professions," Sociological Theory 23: 245-274.

Abbott, L., Parker, S., and Peters, J. 2004. "Audit committee characteristics and restatements," Auditing: A Journal of Practice and Theory 23(1): 69-87.

Ackroyd, S. and Muzio, D. 2007. "The reconstructed professional firm explaining change in English legal practices," Organization Studies 48: $1-19$.

Albrecht, G. L. and Levy, J. A. 1982. "The professionalization of osteopathy: Adaptation in the medical marketplace," Research in the Sociology of Health Care 2: 161-206.

Anderson-Gough, F., Grey, C., and Robson, K. 1999. "Making up accountants: the organisational and professional socialisation of trainee chartered accounts," in R. Roslender (ed.), Accounting and Business Research, 29: 259-260. Aldershot: Gower Ashgate.

Anderson-Gough, F., Grey, C., and Robson, K. 2000. "In the name of the client: The service ethic in two international accounting firms," Human Relations 53: 1151-1174.

Arnold, P. J. 2005. "Disciplining domestic regulation: The World Trade Organization and the market for professional services," Accounting, Organizations and Society 30: 299-330.

Arnold, P. J. and Sikka, P. 2001. "Globalization and the state-profession relationship: The case the Bank of Credit and Commerce International," Accounting, Organizations and Society 26: 475-499.

Barber, B. 1963. "Some problems in the sociology of the professions," Daedalus 92: 669-688.

Barber, B. M., Lehavy, R., and Trueman, B. 2007. "Comparing the stock recommendation performance of investment banks and independent research firms," Journal of Financial Economics 85: 490-517.

Batson Report. 2003. The final report of Neal Batson, Court-appointed examiner, in re: ENRON CORP., et al., debtors. United States Bankruptcy Court, Southern District of New York.

Begun, J. W. and Lippincott, R. C. 1987. "The origins and resolution of interoccupational conflict," Work and Occupations 14: 368-386. 
Blouin, J., Grein, B., and Roundtree, B. 2007. "An analysis of forced auditor change: The case of former Arthur Andersen clients," The Accounting Review 82: 621-650.

Braun, R. L. 2000. "The effect of time pressure on auditor attention to qualitative aspects of misstatements indicative of potential fraudulent financial reporting," Accounting, Organizations and Society 25: 243-259.

Brint, S. G. 1994. In an Age of Experts: The Changing Role of Professionals in Politics and Public Life. Princeton University Press.

Briscoe, F. and Von Nordenflycht, A. 2014. "Which path to power? Workplace networks and the relative effectiveness of inheritance and rainmaking strategies for professional partners," Journal of Professions and Organization 1(1): 33-48.

Brock, D., Powell, M., and Hinings, C. R. 1999. Restructuring the Professional Organization: Accounting, Healthcare and Law. London and New York: Routledge.

Broom, G. and Bandel, C. 2014. "Swiss banks send U.S. client data before cascade of accords," Bloomberg Business, July 31.

Broschak, J. 2015. "Client Relationships in Professional Service Firms," in L. Empson, D. Muzio, J. Broschak, and B. Hinings (eds.), The Handbook of Professional Services Firms: 304-326. Oxford University Press.

Burger, E. S., Mayer, D., and Bowal, P. 2007. "KPMG and abusive tax shelters: Key ethical implications for legal and accounting professionals," Journal of Legal Profession 31: 43-74.

Burrage, M., Jaraush, K., and Siegrist, H. 1990. "An actor based framework for the study of professionalism," in M. Burrage and R. Torstendahl (eds.), The Professions in Theory and History: 202-226. London: Rutledge.

Burrage, M. and Torstendahl, R. 1990. Professions in Theory and History. London: Sage.

Cameron, C. 2002. "Hired guns and smoking guns: McCabe v British American Tobacco Australia Ltd," University of New South Wales Law Journal 25: 768-773.

Caramanis, C. V. 2002. "The interplay between professional groups, the state and supranational agents: Pax Americana in the age of 'globalisation,"” Accounting, Organizations and Society 27: 379-408.

Carr-Saunders, A. M., and Wilson, P. A. 1933. The Professions. Oxford: Clarendon Press.

CFA. 2013. Code of Ethics and Standards of Professional Conduct. 
Coffee, J. C. 2005. "A Theory of Corporate Scandals: Why the U.S. and Europe Differ." Columbia Law and Economics Working Paper No. 274.

Coffee, J. C. 2006. Gatekeepers: The Professions and Corporate Governance. Oxford University Press.

Cooper, D., Hinings, C. R., Greenwood, R., and Brown, J. L. 1996. "Sedimentation and transformation in organizational change: The case of Canadian law firms," Organization Studies 17: 623-647.

Cooper, D., Lowe, A., Puxty, A., Robson, K., and Willmott, H. 1988. Regulating the UK Accountancy Profession: Episodes in the Relation Between the Profession and the State. Paper presented at the Economic and Social Research Council Conference on Corporatism at the Policy Studies Institute, London, January.

Cooper, D. L. and Robson, K. 2006. "Accounting, professions and regulation: Locating the sites of professionalization," Accounting, Organizations and Society 31: 415-444.

Court of Milan. 2008. I Section Criminal Law. Sentence. N. 10465/04 R.G. n.r. N. $12473 / 04+7436 / 08+9538 / 05$ R.G. Trib.

Covaleski, M. A., Dirsmith, M. L., Heian, J. B., and Samuel, S. 1998. "The calculated and the avowed: Techniques of discipline and struggles over identity in Big Six public accounting firms," Administrative Science Quarterly 43: 293-327.

Crotty, J. 2009. "Structural causes of the global financial crisis: A critical assessment of the "new financial architecture," Cambridge Journal of Economics 33: 563-580.

Crump, R. 2013. "FRC warns auditors over ethical failings," Accountancy Age. May 29.

Cullinan, C. 2004. "Enron as a symptom of audit process breakdown: Can the Sarbanes-Oxley Act cure the disease?," Critical Perspectives in Accounting 15: 853-864.

Daly, M. C. and Silver, C. 2006. "Flattening the world of legal services: The ethical and liability minefields of offshoring legal and law-related services," Georgetown Journal of International Law 38: 401-447.

DeFond, M. L. and Francis, J. R. 2005. "Audit research after Sarbanes-Oxley,” Auditing: A Journal of Practice \& Theory 25: 5-30.

Dinovitzer, R., Gunz, H., and Gunz, S. 2014. "Unpacking client capture: Evidence from corporate law firms," Journal of Professions and Organization 1: 99-117.

Dinovitzer, R., Gunz, H., and Gunz, S. 2015. "Professional ethics: Origins, applications and developments," in L. Empson, D. Muzio, J. Broschak, 
and B. Hinings (eds.), The Handbook of Professional Services Firms: 113-134. Oxford University Press.

Dowell, K. 2012. "Russell Jones \& Walker acquired by listed Aussie firm Slater \& Gordon," The Lawyer. Available from: www.thelawyer.com/analysis/ the-lawyer-management/abs-news-and-analysis/russell-jones-and-walkeracquired-by-listed-aussie-firm-slater-and-gordon/1011140.article [Acessed: January 30, 2012].

Dugar, A. and Nathan, S. 1995. "The effect of investment banking relationships on financial analysts' earnings forecasts and investment recommendations," Contemporary Accounting Research 12: 131-160.

Durkheim, E. 1957. Professional Ethics and Civic Morals. London: Routledge and Kegan Paul.

Empson, L. and Chapman, C. 2006. "Partnership versus corporation: Implications of alternative forms of governance in professional service firms," Research in the Sociology of Organizations 24: 139-170.

Empson, L., Muzio, D., Broschak, J., and Hinings, B. 2015. "Introduction,” in L. Empson, D. Muzio, J. Broschak, and B. Hinings (eds.), The Handbook of Professional Services Firms: 1-22. Oxford University Press.

Etherington, L. and Lee, R. 2007. "Ethical codes and cultural context: Ensuring legal ethics in the global law firm," Indiana Journal of Global Legal Studies 14: 95-118.

Faulconbridge, J. R. and Muzio, D. 2007. "Re-inserting the professional in the study of PSFs," Global Networks 7: 249-270.

Faulconbridge, J. R. and Muzio, D. 2008. "Organizational professionalism in globalizing law firms,” Work, Employment \& Society 22: 7-25.

Faulconbridge, J. R. and Muzio, D. 2009. "The financialization of large law firms: Situated discourses and practices of organization," The Journal of Economic Geography 9: 641-661.

Faulconbridge, J. R. and Muzio, D. 2012. "The rescaling of the professions: towards a transnational sociology of the professions," International Sociology 27: 109-125.

Flood, J. 2011. "The re-landscaping of the legal profession: Large law firms and professional re-regulation," Current Sociology 59: 507-529.

Forbes Report. 2003. Final report of Neal Batson, court-appointed examiner. Chapter 11, Case No. 01-16034 (AJG). Jointly Administered.

Fortney, S. and Gordon, T. 2013. "Adopting law firm management system to survive and thrive: A study of the Australian approach to management-based regulation," University of St. Thomas Law Journal 10: 152 . 
Freidson, E. 1970. Profession of Medicine: A Study of the Sociology of Applied Knowledge. New York: Dodd, Mead \& Co.

Freidson, E. 1984. "The changing nature of professional control," Annual Review of Sociology 10: 1-20.

Freidson, E. 1994. Professionalism Reborn: Theory, Prophecy, and Policy. University of Chicago Press.

Freidson, E. 2001. Professionalism: The Third Logic. University of Chicago Press.

Gabbioneta, C., Greenwood, R., Mazzola, P., and Minoja, M. 2013. "The influence of the institutional context on corporate illegality," Accounting, Organizations and Society 38: 484-504.

Gabbioneta, C., Prakash, R., and Greenwood, R. 2014. "Sustained corporate corruption and processes of institutional ascription within professional networks," Journal of Professions and Organization 1: 16-32.

Gannagé-Stewart, H. 2014. "Slater \& Gordon completes Pannone takeover." The Lawyer. Available from: www.thelawyer.com/analysis/ the-lawyer-management/merger-watch/slater-and-gordon-completes-p annone-takeover/3016466.article [Accessed: February 17, 2015].

Grey, C. 1998. "On being a professional in a Big Six firm," Accounting, Organizations and Society 23: 569-587.

Grey, C. 2003. "The real world of Enron's auditors," Organization 10: 572-576.

Goode, W. J. 1957. "Community within a community: The professions," American Sociological Review 22: 194-200.

Goode, W. J. 1960. “The profession: reports and opinion," American Sociological Review 25: 902-965.

Goode, W. J. 1969. "The theoretical limits of professionalization," in A. Etzioni (ed.), The Semi-Professions and Their Organization: 266-313. New York: Free Press.

Greenwood, E. 1957. “Attributes of a profession,” Social Work 2: 45-55.

Greenwood, R. 2007. "Your ethics," in L. Empson (ed.), Managing the Modern Law Firm: 186-195. Oxford University Press.

Greenwood, R. and Empson, L. 2003. "The professional partnership: Relic or exemplary form of governance?," Organization Studies 24: 909-933.

Greenwood, R. and Hinings, C. R. 1993. "Understanding strategic change: The contribution of archetypes," Academy of Management Journal 36: 1052-1081.

Greenwood, R., Hinings, C. R., and Brown, J. 1990. “'P2-form' strategic management: Corporate practices in professional partnerships," Academy of Management Journal 33: 725-755. 
Greenwood, R. and Suddaby, R. 2006. "Institutional entrepreneurship in mature fields: The big five accounting firms," Academy of Management Journal 49: 27-48.

Gunz, H. P. and Gunz, S. P. 2008. "Client capture and the professional service firm," American Business Law Journal 45: 685-721.

Halpern, S. A. 1992. "Dynamics of professional control: Internal coalitions and crossprofessional boundaries," American Journal of Sociology 97: 994-1021.

Harrington, B. 2015. "Going global: professionals and the micro-foundations of institutional change," Journal of Professions and Organization 2(2): 103-121.

Hayward, M. L. A. and Boeker, W. 1998. "Power and conflicts of interest in professional firms: Evidence from investment banking," Administrative Science Quarterly 43: 1-22.

Heinz, J. P. 1982. “The power of lawyers,” Georgia Law Review 17: 891-911. Johnson, T. J. 1972. Professions and Power. London: Macmillan.

Kershaw, D. and Moorhead, R. 2013. "Consequential responsibility for client wrongs: Lehman Brothers and the regulation of the legal profession," The Modern Law Review 76: 26-61.

Kipping, M., Kirkpatrick, I., and Muzio, G. D. 2006. “Overly controlled or out of control? Management consultants and the new corporate professionalism," in John., C. (ed.), Production Values: Futures for Professionalism: 153-168. DEMOS: London.

Kish-Gephart J. J., Harrison D. A., and Treviño, L. K. 2010. "Bad apples, bad cases, and bad barrels: Meta-analytic evidence about sources of unethical decisions at work," Journal of Applied Psychology 95: 1-31.

Klimentchenko, D. A. 2009. "Myth of auditor independence," University of Illinois Law Review: 1275-1299.

Krause, E. A. 1996. Death of the Guilds. New Haven, CT: Yale University Press.

Kronus, C. L. 1976. "The evolution of occupational power an historical study of task boundaries between physicians and pharmacists," Work and Occupations 3: 3-37.

Larson, M. S. 1977. The Rise of Professionalism: A Sociological Analysis. The University of California Press.

Leicht, K. T. and Fennell, M. L. 1997. "The changing organizational context of professional work," Annual Review of Sociology 23: 215-231.

Leicht, K. and Fennell, M. 2001. Professional Work: A Sociological Approach. Oxford: Blackwell. 
Le Mire, S. 2007. "The case study: James Hardie and its implications for the teaching of ethics," in B. Naylor and R. Hyams (eds.), Innovation in Clinical Legal Education: Educating Lawyers for the Future: 237-241. Melbourne: Cambridge University Press.

Levitt, A. 2000. Renewing the Covenant with Investors. New York University. Centre for Law and Business. May 10th, 2000.

Lin, H. W. and McNichols, M. F. 1998. "Underwriting relationships, analysts' earnings forecasts and investment recommendations," Journal of Accounting and Economics 25: 101-127.

Lipartito, K. J. and Miranti, P. J. 1998. "Professions and organizations in twentieth-century America," Social Science Quarterly 79: 301-320.

MacDonald, K. M. 1995. The Sociology of the Professions. London: Sage.

Macey, J. R. and Sale, H. A. 2003. "Observations on the role of commodification, independence, and governance in the accounting industry," Villanova Law Review 48: 1167-1187.

Maister, D. H. 1993. Managing the Professional Service Firm. New York: The Free Press.

Malhotra, N., Morris, T., and Hinings, C. B. 2006. "Variation in organizational form among professional service organizations," Research in the Sociology of Organizations 24: 171-202.

Manning, J. 2015. "Gateley IPO: demand high as firm raises $£ 30 \mathrm{~m}$ from first legal IPO," The Lawyer. Available from: www.thelawyer.com/gateley-ipodemand-high-as-firm-raises-30m-from-first-legal-ipo/3035946.article [Acessed: June 8, 2015].

Markle, T. 2014. "A call to partners with outside capital. The non-lawyer investment approach must be updated," Arizona State Law Journal 45: 1251.

McKenna, C. D. 2006. The World's Newest Profession: Management Consulting in the Twentieth Century. New York: Cambridge University Press.

Michaely, R. and Womack, K. L. 1999. "Conflict of interest and the credibility of underwriter analyst recommendations," Review of Financial Studies 12: 653-86.

Millerson, G. 1964. The Qualifying Associations: A Study in Professionalization. London: Routledge \& Kegan Paul.

Mitchell, A. and Sikka, P. 2011. The Pin-stripe Mafia: How Accounting Firms Destroy Societies. Basildon, UK: Association for Accountancy \& Business Affairs.

Mitchell, A., Sikka, P., Christensen, J., Morris, P., and Filling, P. 2002. No Accounting for Tax Havens. Basildon, UK: Association for Accountancy \& Business Affairs. 
Muzio, D., Brock, D. M., and Suddaby, R. 2013. "Professions and institutional change: Towards an institutionalist sociology of the professions," Journal of Management Studies 50: 699-721.

Myers, J., Myers, L., and Omer, T. 2003. "Exploring the term of the auditor-client relationship and the quality of earnings," The Accounting Review 78(3): 779-799.

Nagel, M. T. 2007. "Double deontology and the CCBE: Harmonizing the double trouble in Europe," Washington University Global Studies Law Review 6: 455-481.

Nicolson, D. and Webb, J. S. 1999. Professional Legal Ethics: Critical Interrogations. Oxford University Press.

Novack, J. 2012. "Latest U.S.-Swiss deal makes clear: No hiding cash in big Swiss banks," Forbes, June 21.

O’Brien, P. C., McNichols, M. F., and Hsiou-Wei, L. 2005. "Analyst impartiality and investment banking relationships," Journal of Accounting Research 43: 623-650.

Pache, A. and Santos, F. 2010. "When worlds collide: The internal dynamics of organizational responses to conflicting institutional demands," Academy of Management Review 35: 455-476.

Palan, R., Murphy, R., and Chavagneux, C. 2010. Tax Havens: How Globalization Really Works. Ithaca, NY: Cornell University Press.

Palmer, D. 2012. Normal Organizational Wrongdoing: A Critical Analysis of Theories of Misconduct in and by Organizations. Oxford University Press.

Parker, C. E. 2004. "Law firms incorporated: How incorporation could and should make firms more ethically responsible," University of Queensland Law Journal 25: 347.

Parker, C. E., Evans, A. H., Haller, L. R., Le Mire, S., and Mortensen, R. G. 2008. "The ethical infrastructure of legal practice in large law firms: Values, policy and behaviour," The University of New South Wales Law Journal 31: 158-188.

Parker, C. E., Gordon, T., and Mark, S. 2010. "Regulating law firms ethics management: An empirical assessment of an innovation in regulation of the legal profession in New South Wales," Journal of Law and Society 37: 466-500.

Parsons, T. 1954. Professional and Social Structure. In Essays in Sociological Theory. Glencoe, IL: Free Press.

Partnoy, F. 2009. Legal Studies Research Paper Series Research Paper No. 09-014 Rethinking Regulation of Credit Rating Agencies: An Institutional Investor Perspective. 
Paterson, I., Fink, M., and Ongus, A. 2003. "Economic impact of regulation in the field of liberal professions in different Member States," Research Report Institute for Advanced Studies, Vienna - Study for the European Commission, DG Competition - Available from www.google.co.uk/url? $\mathrm{sa}=\mathrm{t} \& \mathrm{rct}=\mathrm{j} \& \mathrm{q}=\&$ esrc $=\mathrm{s} \&$ source $=$ web $\& \mathrm{~cd}=2 \& v e d=0 \mathrm{CC} 8 \mathrm{QFj} A B \&$ url $=$ http $\% 3 \mathrm{~A} \% 2 \mathrm{~F} \% 2 \mathrm{Fec}$.europa.eu $\% 2 \mathrm{Fcompetition} \% 2 \mathrm{Fsectors} \% 2 \mathrm{Fprofes}$ sional_services\%2Fstudies\%2Fexecutive_en.pdf\&ei=7oDWU9chiNjsBq yngIAP\&usg=AFQjCNHHYE3m9ubt7lKuzX6IGYq5nKpIxg\&bvm=bv .71778758,d.ZGU [Acessed July 28, 2014].

Public Prosecutor Parma. 2010. Notice of termination of preliminary investigations, art. 415/bis, Italy's Code of Criminal procedure (CPP).

Rayne, R. 2014. "Do U.S. firms need external equity investments to remain competitive?," Texas International Law Journal 49: 559.

Reynolds, M. A. 2000. "Professionalism, ethical codes and the internal auditor: A moral argument," Journal of Business Ethics 2492: 115-124.

Ribstein, L. E. 2003. "Bubble laws," Houston Law Review 40: 77-97.

Roberts, S. 1994. "Fictitious capital, fictitious spaces: The geography of offshore financial flows," in S. Corbridge, N. Thrift, and R. Martin (eds.), Money, Power and Space: 91-115. Oxford: Blackwell.

Rosen, R. 2002. “'We're all consultants now': How change in client organizational strategies influences change in the organization of corporate legal services," Arizona Law Review 22: 637-684.

Sako, M. 2015. "Outsourcing and offshoring of professional services," in L. Muzio, D. Muzio, J. Broschak, and B. Hinings (eds.), The Handbook of Professional Services Firms: 327-347. Oxford University Press.

Santoro, M. A. and Strauss, R. J. 2013. Wall Street Values. Business Ethics and the Global Financial Crisis. Cambridge University Press.

SEC, Securities and Exchange Commission. 2000. Final rule: Revision of the Commission's auditor independence requirements, November 21, 2000.

Senate Governmental Affairs Committee. 2002. Rating the raters: Enron and the credit rating agencies. Hearing before the Senate Governmental Affairs Committee, 107th Cong., S. Hrg. 107-471 (March 20, 2002) at 65-66, 122.

Sharma, A. 1997. "Professional as agent: Knowledge asymmetry in agency exchange," Academy of Management Review 22: 758-98.

Shaw, G. B. 2004. The Doctor's Dilemma. Sioux Falls: NuVisions Publications.

Sikka, P. 2009. "Financial crisis and the silence of the auditors," Accounting, Organizations and Society 34: 868-873.

Sikka, P. and Hampton, M. P. 2005. "The role of accountancy firms in tax avoidance: Some evidence and issues," Accounting Forum 29: 325-343. 
Sikka, P. and Willmott, H. 1995. “The power of "independence': Defending and extending the jurisdiction of accounting in the United Kingdom," Accounting, Organizations and Society 20: 547-581.

Slater \& Gordon. 2007. "Prospectus". Available from www.slatergordon.com .au/docs/prospectus/Prospectus.pdf [Accessed: April 23, 2008].

Smets, M., Morris, T., and Greenwood, R. 2012. "From practice to field: A multilevel model of practice-driven institutional change," Academy of Management Journal 55: 877-904.

Suddaby, R., Cooper, D. J., and Greenwood, R. 2007. "Transnational regulation of professional services: Governance dynamics of field level organizational change," Accounting Organizations and Society 32: 333-362.

Suddaby, R., and Muzio, D. 2015. "Theoretical perspective on the professions," in L. Empson, D. Muzio, J. Broschack, and B. Hinings (eds.), The Oxford Handbook of Professional Services Firms: 25-47. Oxford University Press.

Suddaby, R. and Viale, T. 2011. "Professionals and field-level change: Institutional work and the professional project," Current Sociology 59: 423-41.

Sturdy, A. 1997. "The consultancy process - an insecure business?," Journal of Management Studies 34: 389-413.

Terry, L. S. 2001. “'GATS' Applicability to transnational lawyering and its potential impact on US state regulation of lawyers," Vanderbilt Journal of Transnational Law 34: 989-1096.

The Economist. 2014. The dozy watchdogs. December 13: 24-26.

The Lawyer. 2015. Making history: Irwin Mitchell appoints brokers as it eyes 2015 float. Available from: www.thelawyer.com/news/lawyer-news-daily /making-history-irwin-mitchell-appoints-brokers-as-it-eyes-2015-float/ 3030662.article [Acessed: January 22, 2015].

The New York Times. 2001. Enron tries to dismiss finance doubts. October 24.

The New York Times. 2012. The spreading scourge of corporate corruption. October 7.

Thornton, P., Jones, C., and Kury, K. 2005. "Institutional logics and institutional change: Transformation in accounting, architecture, and publishing," in C. Jones and P. Thornton (eds.), Research in the Sociology of Organizations: 125-170. London: JAI.

Urry, J. 2014. Offshoring. London: Polity Press.

von Nordenflycht, A. 2014. "Does the emergence of publicly traded professional service firms undermine the theory of the professional 
partnership? A cross-industry historical analysis." Journal of Professions and Organization 1(2): 137-160.

Wilson, J. M., Boyer O'Leary, M., Metiu, A., and Jett, Q. R. 2008. "Perceived proximity in virtual work: Explaining the paradox of far-but-close," Organization Studies 29: 979-1002.

Wójcik, D. 2013. "Where governance fails: Advanced business services and the offshore world," Progress in Human Geography 37: 330. 